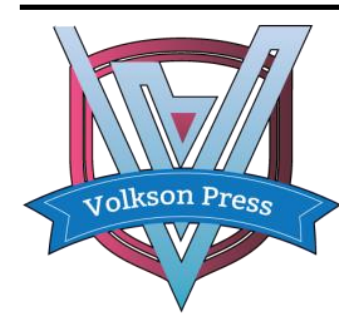

Contents List available at VOLKSON PRESS

Multidisciplinary Inclusive Education, Management

and Legal Services (MIEMLS)

Journal Homepage: https://topicsonsocialdevelop.com

DOI: $10.26480 /$ ismiemls.01.2018.15.17

ISBN : 978-1-948012-13-3

\title{
RESEARCH ON TEACHING REFORM STRATEGY OF LOCAL RUSSIAN INTERPRETATION AND BUSINESS NEGOTIATION
}

\author{
Yu-min Sun \\ Doctor of Philosophy in Russian Linguistics, Director of Russian Centre, Uuniversity of Sanya, China. \\ *Corresponding Author Email: 150085292@qq.com
}

This is an open access article distributed under the Creative Commons Attribution License, which permits unrestricted use, distribution, and reproduction in any medium, provided the original work is properly cited.

\section{ARTICLE DETAILS}

\section{Article History:}

Received 26 June 2018 Accepted 2 July 2018

Available online 1 August 2018

\section{ABSTRACT}

Today, the rapid development of trade between Russia and China undoubtedly puts forward higher requirements for business Russian teaching in local universities. This article analyzes the current status and insufficiency of Russian interpretation and business negotiation teaching in local colleges and universities and proposes corresponding countermeasures. It aims to provide reference for the construction of Russian interpretation and business negotiation courses.

\section{KEYWORDS}

Russian interpretation, international business negotiation, improvement; Curriculum reform.

\section{INTRODUCTION}

In the stable development of Sino-Russian relations, China and Russia are each other's important trading partners. The past decade has witnessed the most frequent double trade activities in the history of China and Russia, with the largest amount of trade and the fastest growing period. This period is also a time when the country is in high demand for highquality, highly-skilled Russian interpreters and business negotiation talents, which also provides a rare opportunity for the development of business Russian subjects. At present, there are still many problems in the construction of local business Russian courses. There is still a certain gap between the business Russian professional talents cultivated by colleges and universities and social needs. The low compoundness of cultivated talents has seriously affected the effective development of China's international business activities. Raising the level of development of business Russian subjects and cultivating compound senior Russian professionals who are both proficient in Russian and understand business knowledge are issues that the relevant institutions urgently need to address.

"Russian interpretation and Business Negotiations" Is an important professional direction course for Russian seniors. It is based on the basic knowledge and vocabulary of business Russian after students completing the course of "Business Russian", It's a comprehensive business training course for the tertiary industry in Hainan Island. The purpose of this course is to teach students to use Russian to solve communication problems. In particular, in the future Hainan Province explores the voyage of building free ports of trade with Chinese characteristics, it is indispensable to strengthen the training of students on practical issues in the third industry trade. By studying this course, students can better master Russian interpreting skills in business negotiations, the process of Russian business negotiation, and familiarize themselves with the Russian business negotiation psychology and related negotiation skills. The course has strong guidance and applicability to the work of business activities in Sino-Russian trade. It enables students to seamlessly connect to business posts, quickly and accurately solve the problems encountered in the actual business negotiation work and reduce the barriers and difficulties of cross-cultural business communication.

In the context of the transformation and development of for eign language teaching, this course plays an important role in the application of Russian business personnel training programs. Its own nature and professional training objectives put higher demands on both teachers and students.

\section{IMPROVEMENT OF TEACHER BUSINESS SKILLS}

\subsection{Theory of knowledge of international business negotiation}

Business Russian is a new and emerging profession in recent years Russian interpretation and business negotiation are a cross-cutting subject (Russian Interpretation + International Business negotiation). Through surveys, the vast majority of teaching teachers lack business knowledge and practical skills. Despite deep language knowledge, but the knowledge structure is single, the teaching process involved in the international business negotiation course need to look of a lot of information. Therefore, for the lack of professional theoretical knowledge of professional Russian language teachers, local colleges and universities can formulate relevant policies, encourage teachers to participate in business knowledge training, increase the collaboration between Russian language teachers and business teachers, and strengthen exchanges and cooperation in teaching at home and abroad, As well as backbone Russian teachers and team building [1].

\subsection{Combining production with teaching to accumulate practical} experience

In the teaching process, because the teachers themselves lack actual combat experience in international business negotiation, they are unable to provide students with substantial skills and guidance, which results in a lack of practicality in the entire teaching process and thus prevents the development of truly useful qualified personnel for the society and for Russian business enterprises. It is necessary to strengthen the training of teachers' practical skills, combine production with teaching, provide teachers with opportunities to participate in Russian-language international business negotiation internships, and enhance the application skills of teachers' theoretical knowledge in business negotiations.

\section{CURRICULUM REFORM}

\subsection{The first step: understand the teaching goals}

At present, the teaching of local Russian business orientation courses mainly adopts traditional foreign language teaching modes, failing to truly reflect the characteristics of international business negotiation disciplines. 
In the teaching process, Russian must to service the business and students should be guided to use Russian as a language tool to learn international business and other theoretical knowledge, instead of simply explaining the use of Russian words and phrase sentences in international business negotiations. After grasping the relationship between Russian and business knowledge, we must design the curriculum module so as not to deviate from our professional talent training goals.

\subsection{Step Two: Establishing Students' Learning Objectives}

Value Objectives: In the teaching process, we must first inspire and guide students to establish correct values in career choices in life goals and establish their understanding and pursuit of Russian business communication activities.

Way of thinking: Different countries and nations have different histories and cultures. Cultural differences will be reflected in all areas of human communication, including business communication in the context of economic globalization. Guide students to contrast the ways of thinking patterns of the Chinese and Russian peoples, cultivate students' correct thinking modes such as trans-positional thinking, seeking common grounds and differences, transplanting ideas, cross-culture, etc.; help students understand the basic theory of cross-cultural communication Knowledge, as a whole, grasps the characteristics of Russian national culture and business negotiating etiquette to avoid misunderstandings and disagreements among students due to cultural differences in their actual work in the future, and to promote trust among partners so as to improve the quality and efficiency of business communication.

Professional Method Objectives: To enable students to master professional methods such as Russian interpretation and translation, Russian practical writing, and cross-cultural communication; to master Russian business correspondence using computers and modern office equipment; and to have business Russian capabilities.

Professional Skills Objectives: To enable students to have the theory and knowledge of cross-cultural business communication; to have professional skills to communicate in Russian; to have an international perspective; to use Russian language to promote the development and common prosperity of business activities between China and Russia; The business etiquette; the language etiquette in cross-cultural communication. Establish a professional image of Russian business trade workers, improve their ability to adapt to Russian business communication, develop students' ability to manage cross-cultural trade and business personnel, develop and promote trade projects, and translate capabilities; have good communication skills and cross-cultural Communication skills.

\subsection{The third step: improvement of teaching methods}

Compared with conventional Russian, Russian business negotiation has the characteristics of professional vocabulary and terminology, strict vocabulary, syntactic specification, and strong legality. For Russian students at the beginning of the university, learning and mastering Russian business negotiations is relatively difficult. As we all know, the Russian language teaching environment in China is completely different from that in Russia. In a Chinese university, the number of students in one class up to one hundred. The number of Chinese class students in Russian is usually $30-50$. In this case, it is difficult to find the entry point for each student. Students may not be able to understand the topics they are trying to understand. Some students may only spend time passively learning foreign languages at this stage. There are difficulties in the teaching of foreign languages at different levels.

To overcome these difficulties, we must first highlight the studentcentered, teacher-led exchange model, based on the "task teaching method" and "group cooperation" and insist on simulating training as a precursor. Students interact and truly realize the "student-centered" teaching model. Each time, the topics, tasks, and case studies are used to explain, discuss, complete tasks, and analyze cases. In the process of personal task assignment, teachers and team leaders must fully consider each student's personality characteristics and overall quality, grasp the principles of "small class, short class hours, strong training, and diversification" and promote the combination of theory and practice.

The concept of modern education proclaims the guiding competent approach, which suggests developing students' soft competencies that would promote their self-reliance and self-organization abilities [2]. At present, there are still deficiencies in our international Russian business negotiation course system, which cannot keep up with the development of business activities. With the rapid development of economic globalization, the content of Russian language teaching materials and courses in international business negotiations must be updated and improved. Therefore, students must be led to make full use of the Internet platform, read the latest business information and theoretical knowledge, and update and improve themselves on time. Teachers send the topic, discussion and tasks to the course teaching platform before class, so that students can study related materials in advance, make notes, and prepare for class.

In the class, teachers only explain the key and difficult words, and do not translate sentence-by-sentence to the core text. Instead, they focus on understanding and discussing the content of the text. According to the student's understanding of the knowledge points, they can selectively complete the corresponding exercises. They mainly use Russian to examine students' mastery of relevant business knowledge, encourage students to boldly use Russian to express their opinions, and guide students to actively read and collect relevant texts. Information, writing special task reports, and giving lectures in class to exercise their self-study, writing, and oral expression skills; practice scenario activities require students to carefully prepare in advance, strive to make the scene more realistic, and help students digest the learned business knowledge. As with vocabulary, Students can read and expand their knowledge on their own to broaden the student's information on the topic. In the teaching process, students are required to purchase the relevant required reading books, and to borrow books from the school library. Before the student group's work is started, the group's list is determined based on their interest in learning, and a trading company is simulated to establish the business content.

During the course of teaching Russian interpretation and business negotiation, we found that the group cooperative teaching method has many teaching advantages. According to the role distribution, the team members know what substantive actions they need to take in the group cooperation: planning, assignment, and team members Coordination and cooperation, comprehensive monitoring and results evaluation. Take the example of a group task in our course "Assignment of preparations before simulating negotiations" [3]. In a group work consisting of 5 individuals, the team leader will first assign tasks to the team members according to the course orientation given by the teacher:

\begin{tabular}{|l|l|}
\hline team members & Task Assignment \\
\hline A Student (Legal Consultant) & China-Russia foreign trade policy in this area \\
\hline B Student (Trade Consultant) & $\begin{array}{l}\text { Various business knowledge that may be involved in the trade process, such as product } \\
\text { knowledge, market knowledge, financial knowledge, transportation, insurance, etc. }\end{array}$ \\
\hline C Student (Trade Manager) & $\begin{array}{l}\text { Select target markets, extensively collect market data through various channels, strengthen } \\
\text { understanding of the supply and sales status and price dynamics of foreign markets, so as to } \\
\text { select the appropriate target market. }\end{array}$ \\
\hline D Student (Trade Manager) & $\begin{array}{l}\text { Select the trading target and analyze the customer's political, cultural background, credit } \\
\text { status, business scope, and operating capabilities through various channels. }\end{array}$ \\
\hline E Student (General manager) & $\begin{array}{l}\text { Formulate business negotiation programs (highest goals, lowest goals, negotiation issues, } \\
\text { order of negotiations, etc., including price issues) }\end{array}$ \\
\hline
\end{tabular}


The task requires that each student can use Russian as a tool to prepare the analytical material (Seminar teaching mode), and finally one student will make the final summary speech. Seminar teaching style is the most common teaching model in European and American universities. It is an interactive teaching and research activity, focusing on students' selflearning ability, research ability and innovation ability.

Here, we must emphasize the necessity of group work. The group work in the foreign language classroom relates to interactive methods, which takes the educative process to a more efficient level. Promotion of students' learning activities and the higher learning motivation, the maximum reach of the target audience blocking off any passive attendance, the need to show to a group the achieved result-"to be highly visible"; the development of personal sociability, teamwork ability and efforts to gain understanding, preventing conflict situations. Additionally, the teamwork enhances interpersonal relationships, teaches better understanding of each other and contributes to sound classroom community. This form of work also serves the ability to adequately assess both oneself and others, provides knowledge sharing, good environment for the development of one's proficiency and quick aid during the teamwork; it increases motivation, uplifts a student's popularity and practical status in the team, diversifies the classroom work forms [4].

The use of group work in the learning activity increases students' acquisition of foreign language speech experience. They start to feel more confident, learn new material quicker and do speaking exercises with lesser mistakes as they have more time to practice speaking Russian with their peers. Working in a group fosters their personal human creativity. The teamwork makes students more active, boosts their motivation to study and get interested in collective success. Students become more selfreliant and proactive, their teamwork with peers in groups promote the sense of community, responsibility and mutual supportiveness [2].

During Russian interpretation and business negotiation courses, teachers should pay attention to intensify students' business negotiation translation skills, guide students to accumulate the related topics and vocabulary, and conduct comprehensive interpretation training to strengthen students' practical ability. On the basis of mastering Russian and business knowledge, related institutions should strengthen interaction with business enterprises, combine production with education and organize students to practice learning in related companies to enhance students' practical ability.

\section{CONCLUSION}

The cultivation of complex Russian-language personnel in business is a complex and arduous task. Advancing the construction of a compound teacher team and strengthening the compounding of teacher language and business knowledge are necessary conditions for the stable and sustainable development of business-combined Russian language teaching. Actively promote the reform of curriculum teaching, a studentcentered and teacher-oriented exchange model need to be highlighted in the teaching process. From school-enterprise cooperation to integration of production and education, students should apply the learned knowledge to specific foreign trade operations. Only in this way can we achieve the goal of high-quality compound international business Russian talent training.

\section{REFERENCES}

[1] He, H. 2016. The Present Situation and Approaches to the Development of Business English in Local Universities Journal of Kaifeng Institute of Education, 36 (5), 103-105.

[2] Sun, Y., Mikitchenko, E.S. 2017. Group Forms of Students' Activities in Classroom of Russian as a Foreign Language Advanced education and management engineering, 100-105.

[3] Cellich, C., Jain, S.C. 2013. International Business Negotiation" China Renmin University Press, 210.

[4] Passov, E.I. 1998. The foreign language lesson at secondary school, M.: Prosveshchenie,153.

\section{ABOUT THE AUTHORS}

Yu-min Sun Doctor of philosophy in Russian linguistics, Lecturer, Graduated from the Dnepropetrovsk national university (Ukriane) in 2012, Worked in University of Sanya (China), Director of Russian center. Her research interests include business Russian language, Russian language and culture. 